\title{
Legal Due to Cancellation of Grants in Perspective of Legal Certainty
}

\author{
Daris Ramadhannisa Suroto ${ }^{1} \quad$ M. Al Haadi Nugraha ${ }^{2} \quad$ Mulia Akbar Santoso $^{3} \quad$ Umar Dinata $^{4}$ \\ M. Valiant Arsi Nugraha ${ }^{5}$ Indriya Fathni ${ }^{6}$
}

\begin{abstract}
This study aims to find out and analyze the judge's legal considerations in canceling the grant deed and the legal consequences of canceling the grant deed that has been made by the Land Titles Registrar (PPAT). From these objectives, the problem can be formulated, namely: What are the legal considerations of the judge in canceling the grant deed and what are the legal consequences of canceling the grant deed that has been made by PPAT. To answer these problems, the method used in this research is normative juridical, which is a type of research that examines the legal consequences of canceling a grant deed in the perspective of legal certainty. The results of this study prove that the judge's legal considerations in canceling the grant deed are based on statutory regulations, among others based on the Civil Code, Islamic Law Compilation (KHI), and Syariah Economic Law Compilation (KHES). While, the legal consequences of canceling the grant deed made by PPAT i.e. it can be null and void and/or can be canceled. Cancel by law and/or can be canceled, if it does not meet the legal requirements of an agreement. Cancel by law in the discussion, namely the object of the grant and the deed of grant made by PPAT are considered to never exist and returned as before to the grantor. As a recommendation from the research, among others are: there should be stricter and clearer regulations governing grants and their cancellations to ensure legal certainty and PPAT and government officials should be able to provide legal counseling related to the regulations that should be to the public will do grant or cancel a grant.
\end{abstract}

Keywords: Legal consequences, cancellation of grant deed, legal certainty.

DOI: $10.7176 / \mathrm{JLPG} / 115-03$

Publication date: November $30^{\text {th }} 2021$

\section{INTRODUCTION}

At this time, grant issues often end up in court. Grants can be made by anyone who has no close kinship or close blood relationship, for example: a neighbor's child; cousins, and so on who are not heirs. The grant is carried out when the grantor is still alive, different from the heir. Inheritance is open and can be executed when the beneficiary dies. The grant is given to someone who is not an heir or who has a close kinship. In carrying out the grant, it should be known by the heirs or families who have close kinship relationships so that it does not become a problem in the future. Grants can be in the form of movable or immovable objects. Usually the grant is carried out using the services of PPAT in accordance with the rules of the duties and principal authorities of the PPAT in the Government Regulation of the Republic of Indonesia Number 37 of 1998 concerning the Regulation of the Position of the Official for Making Land Deeds. One of them is making a deed of grant. PPAT is devoted to immovable objects such as land, to assist the process of changing names in land management.

The making of the Grant Deed is the authority of the PPAT which is basically CHAPTER II Article 2 number 2 concerning the Main Duties and Authorities of the PPAT Government Regulation of the Republic of Indonesia Number 37 of 1998 concerning the Regulation of the Position of the Land Deed Making Official which determines the legal actions as referred to in paragraph (1), one of which is a grant.

In carrying out his duties and authorities as a PPAT he must comply with the applicable rules and must know the regulations relating to grants, so that it does not become a problem in the future and the PPAT must provide legal counseling to his clients.

Grants can be made to anyone, whether a Muslim or a non-Muslim. If those who carry out the grant are Muslims, then there is a dispute and the deed made is problematic, then the authority of the Religious Courts which has the authority to adjudicate according to the rules in Article 49 of Law of the Republic of Indonesia Number 3 of 2006 concerning Amendments to Law Number 7 of 1989 Regarding the Religious Courts, which determines that religious courts have the duty and authority to examine, decide, and resolve cases at the first level between people who are Muslim, one of which is in the field of grants.

A grant is a one-sided agreement, where there is only one person who excels. Grants according to the Compilation of Islamic Law Article 171 letter $g$ are the giving of an object voluntarily and without compensation

\footnotetext{
${ }^{1}$ Student of the Notary Masters Study Program, Faculty of Law, Universitas Jambi.

${ }^{2}$ Student of the Doctor of Law Studies Program, Faculty of Law, Universitas Jambi.

${ }^{3}$ Student of the Doctor of Law Studies Program, Faculty of Law, Universitas Jambi.

${ }^{4}$ Student of the Doctor of Law Studies Program, Faculty of Law, Universitas Jambi.

${ }^{5}$ Student of the Doctor of Law Studies Program and a Lecturer at the Faculty of Law, Universitas Jambi.

${ }^{6}$ Student of the Doctor of Law Studies Program and a Lecturer at the Faculty of Law, Universitas Jambi.
} 
from someone to another person who is still alive to be owned. Grants according to the Compilation of Sharia Economic Law Article 668 Book III concerning Zakat and Grants. A grant is the transfer of ownership of an item to another person without any reward.

In the provision of grants, of course there are conditions and rules, especially regarding grants, which are regulated in the Civil Code, the Compilation of Islamic Law and the Compilation of Sharia Economic Law. In one of the rules, the grant may not exceed $1 / 3$ of the total assets owned by the grantor. Legal certainty in grant arrangements must be obtained by the community in order to make a peaceful, prosperous and just country. In this case, the government and state apparatus play an important role in providing legal counseling to the community in order to minimize problems related to grants. In grant arrangements, grants are irrevocable there are several things that can make the grant cancelled. With some existing conditions, if the grant is detrimental to the heirs, then the grant is submitted for cancellation to the Court.

\section{FORMULATION OF THE PROBLEM}

Based on the preliminary description above, the problem can be formulated:

1. What are the judges' legal considerations in canceling the grant deed?

2. What are the legal consequences of canceling the grant deed that has been made by PPAT?

\section{RESEARCH METHODS}

The method used in this research is normative juridical. normative juridical, namely the type of research that is a type of research that examines the legal consequences of canceling a grant deed in the perspective of legal certainty. In addition, the type of normative juridical research in a research or study of normative legal science can be interpreted as an activity to explain the law, so there is no need for data support or social facts, because normative legal science does not recognize social data or facts which are known only as legal materials or to seek information. The meaning and value of the law is only used by legal concepts and the steps taken are normative steps.

\section{LEGAL CONSIDERATIONS IN CANCELLATION OF GRANTS}

According to R. Subekti, a grant or what is defined as a schenking gift is an obligatory agreement, in which one party undertakes to give free om niet by absolutely giving an object and the other party is the party who receives the gift. As an agreement, the gift is immediately binding and cannot be withdrawn simply according to the will of a party. ${ }^{2}$

Grants are regulated in the Civil Code, the Compilation of Islamic Law, and the Compilation of Economic Law. Grants are regulated in the Civil Code Chapter X concerning grants, this contains the understanding and general provisions regarding grants, the ability to give and receive grants, how to donate something, as well as revocation and cancellation of grants. Compilation of Islamic Law which is the Decree of the Minister of Religion of the Republic of Indonesia Number: 154 of 1991 concerning Implementation of Presidential Instruction of the Republic of Indonesia Number 1 of 1991 Dated June 1, 1991 Article 210-214, Compilation of Sharia Economic Law Articles 685,-727, Book III concerning Zakat and Grants . Before going any further, it is better to know the meaning of compilation first. Compilation is a collection of opinions of Indonesian scholars originating from the Qur'an and Hadith. The Compilation of Islamic Law and the Compilation of Economic Law are used as the basis of the judges of the panel of judges of the Religious Courts to settle a case in the Religious Court, the rest of the judges are also guided by other regulations relating to the problem being resolved.

A grant is a one-sided agreement, where there is only one person who excels. A grant is a gift that is made while the grantor is still alive to someone without any remuneration for services. A grant according to Article 1666 of the Civil Code is an agreement whereby the donor in his lifetime irrevocably surrenders an object for the purposes of the recipient of the grant who receives the delivery ${ }^{3}$.

The grant is an agreement in the Civil Code, therefore it is closely related to the Articles relating to the Agreement. In Article 1313 which stipulates that an agreement is an act by which one or more persons bind themselves to one or more persons. Everyone has the right to make an agreement by taking into account the legal terms, the agreement between them is also recognized by the Civil Code. In Article 1338 of the Civil Code which stipulates that a valid agreement is considered the same as the law, for those who make it.

In the agreement, of course, there are legal conditions, which are regulated in Article 1320, namely: agreeing, being competent, a certain thing, and because it is a lawful thing. If it does not meet these requirements, then the agreement is invalid and can be null and void or can be canceled. Canceled by law, namely the agreement is considered to have never existed or was born at all (but still submitted to the Court) while it can be canceled, namely it is considered to have existed or was born from the beginning, but must be submitted or

${ }^{1}$ Bahder Johan, Legal Research Methods, Mandar Maju, Bandung, 2008, p. 87

${ }^{2}$ R. Subekti, Various Agreements, Citra Aditya Bakti, Bandung, 1999. p. 95

${ }^{3}$ Herlien Budiono, General Doctrine of Covenant Law and Its Application in the Notary Sector, Citra Aditya Bakti, Bandung, 2010 , p. 55. 
canceled by a person with an interest in the competent institution, namely the Court (Judge's Determination) Agree and Capable are subjective conditions and the consequences if they do not meet it can be canceled. A certain thing and a lawful clause that does not conflict with the regulations, this is an objective requirement, the consequence is that if it is not fulfilled, it can be canceled by law.

Basically, the grant is made by two parties, but only one person excels and the other performs the achievement. Even though the grant has been made before a Notary/PPAT, the possibility for the withdrawal or revocation of the grant is very there, namely canceling the grant. In the Civil Code and the Compilation of Islamic Law, the withdrawal and revocation of grants may not be carried out unilaterally and without the consent of the grantee. Although the grant is made between two people who are relatives or husband and wife, the grant that can be withdrawn according to Article 212 of the Compilation of Islamic Law is a parent's gift to his child. In the deed of grant, if the terms of the grant have been violated and the terms of cancellation of the deed of grant can be proven by the Plaintiff, the Panel of Judges will cancel the deed of grant. Article 712 of the Compilation of Sharia Economic Law, which stipulates "The grantor may withdraw his/her assets after the delivery is carried out, provided that the recipient agrees".

Article 1688 of the Civil Code stipulates: "a grant cannot be withdrawn or written off because of it, but in the following cases:

1. because the conditions under which the grant has been made are not met;

2. If the grantee has been guilty of a crime aimed at taking the soul of the donor or some other crime against the donor;

3. If he refuses to provide a living allowance to the donor, after this person has fallen into poverty."

Based on the article, it is clear that there are things that can cancel a grant between the recipient and the grantor. The withdrawal is stated in the will of the grantor to the grantee with a demand for the return of the goods. It is possible that the grantee retains his rights which according to him are in accordance with the applicable regulations, in this case one of the parties who feel aggrieved can sue and ask for his rights through the Court. If the implementation can harm the rights of others, then any party who feels that their rights have been harmed can apply for cancellation in court as well if they agree that there is an element in Article 1321 of the Civil Code there is an element of error, or it was obtained by coercion or fraud. Thus, the grant can be invalid because the implementation of the grant deviates from the existing regulations in the Civil Code.

Legal efforts made to claim rights can file a lawsuit to the Court, for the judge to examine and decide on the disputed case. Regarding the process in court regarding the cancellation of the grant deed is not easy, because it requires proof. Therefore, the cancellation of the grant deed carried out using the PPAT (Land Titles Registrar) deed can be submitted through the competent Court. The judge's consideration in the cancellation of the grant deed is based on the rules guided by the judge, besides that the judge also has the right to create the law of Rechtsvinding (Invention of law) and Rechtsschepping (Creation of law). The basis of the judge's authority is contained in Law Number 48 of 2009 concerning Judicial Power.

\section{IMPLICATIONS OF CANCELLATION OF GRANTS DED BY PPAT}

Legal consequences are all consequences, consequences that occur from all legal actions carried out by legal subjects against legal objects or other consequences caused by certain events which by the law in question itself have been determined or considered as legal consequences. ${ }^{1}$

In the agreement, of course, there are legal conditions, which are regulated in Article 1320, namely: agreeing, being competent, a certain thing, and because it is a lawful thing. If it does not meet these requirements, then the agreement is invalid and can be null and void or can be canceled. Canceled by law, namely the agreement is considered to have never existed or was born at all (but still submitted to the Court) while it can be canceled, namely it is considered to have existed or was born from the beginning, but must be submitted or canceled by a person with an interest in the competent institution, namely the Court (Judge's Determination) Agree and Capable are subjective conditions and the consequences if they do not meet it can be canceled. A certain thing and a lawful clause that does not conflict with the regulations, this is an objective requirement, the consequence is that if it is not fulfilled, it can be canceled by law. Grants are usually carried out in the form of movable or immovable objects. If the grant has been implemented, it will be resolved in the competent Court.

The legal consequences if the grant deed made by PPAT (Land Deed Making Officer) is not in accordance with what is regulated, for example in a case PPAT (Land Titles Registrar) makes a grant deed by exceeding the maximum grant, which is more than $1 / 3$ of the total assets of the giver. Grant, then the heirs, namely his biological children, did not know and finally sued the biological mother and his mother's brother to the Religious Court, because they are Muslims. The child did not accept and felt that he had no rights and sense of concern for

${ }^{1}$ La Ode Angga, Legal Consequences of the Absence of Spatial Planning Supervision and Evaluation Arrangements in the Maluku Provincial Regional Regulation, Journal of Legal Studies, Vol.1, No. 2.2016, p. 6. 
his life, and he wanted to cancel the grant because the land was the only property owned by his mother.

This has violated the rules, the granting exceeds $1 / 3$ of the total assets of the grantor, therefore it is related to Article 1320 of the Civil Code letter 4 clause which is lawful. This is contrary to the legal terms of the agreement, it results in null and void. Canceled by law, the act or agreement is considered to have never existed or was born, as well as the deed made by the PPAT (Land Title Registrar).

Deed is a deed derived from the Latin "acta" which means letter. Meanwhile, according to R. Subekti and Tjitrosudibio in the legal dictionary, the word "acta" is the plural form of the word "actum" which comes from Latin and means actions. According to Sudikno Mertokusumo, a deed is a signed letter, which contains legal events, which form the basis of a right or an engagement, which was made from the beginning intentionally for the purpose of proof. ${ }^{1}$ Deed is a certificate containing legal actions made by or authorized officials. ${ }^{2}$ An authentic deed according to the Civil Code is "a deed in the form determined by law, made by or before public officials who have power for that at the place where the deed was made".

The specialty of an authentic deed is that it is a perfect proof of what is contained in it. If someone submits an authentic deed to the judge as evidence, the judge must accept and consider what is written in the deed, an event that has really happened and the judge may not order additional evidence. ${ }^{3}$

The legal consequences for the object of the grant whose actions have been decided by the judge that the deed of the grant and the grant are null and void by law. Thus, all the assets that he had donated in the past will become his own property or return to the original owner. All actions that are not in accordance with the legal requirements can be null and void by law and returned to their original state and considered never to have been born, returned to their original owner, namely the grantor. Anyone who obtains rights from the object of the dispute is required to dismantle all the buildings that are his rights and vacate the disputed land from all his rights, then hand over the land to the original owner as the grantor. If necessary, in the clearing of this land, use the assistance of the State apparatus. With the emptying of the disputed object and the return of property rights to the original owner, the documents that have been in the name, such as land titles, certificates and others under the name of the grantee, become null and void.

\section{CONCLUSION}

Based on the description above, it can be concluded, as follows:

1. Judge's legal considerations in canceling the grant deed based on statutory regulations, among others based on the Civil Code, KHI (Islamic Law Compilation, and KHES (Shariah Economic Law Compilation) as well as by creating Rechtsvinding (legal invention) and Rechtsschepping (law creation) laws the basis of the authority of judges is contained in Law Number 48 of 2009 concerning Judicial Powers;

2. The legal consequences of canceling the grant deed made by PPAT (Land Titles Registrar) that can be null and void by law and/or can be canceled. It is null and void and can be canceled, if it does not meet the legal requirements of an agreement. Canceled by law in the discussion, namely the object of the grant and the deed made by the PPAT is considered to never exist and is returned as before to the grantor.

\section{SUGGESTION/RECOMMENDATION}

Before ending this paper, it is necessary to put forward some suggestions as a solution to the various problems found, including:

1. There is a need for legal clarity and certainty, this is very important in determining justice, therefore, the rules relating to the cancellation of grants or grants must be clear and should as well as the authorized official including PPAT provide legal counseling related to the grant;

2. With the grants made by the grantor directly and entirely to people who are not children, what he owns can sometimes cause problems because he has close heirs, namely children or husbands who feel they have their rights in it. So that problems often occur when things are not in accordance with what is desired when giving a grant or when a grant has occurred. Therefore, before giving a grant, it is necessary to carefully consider what will happen in the future and on a basis that is in accordance with applicable regulations in Indonesia. In its implementation, the granting of a grant must meet various applicable provisions or norms, namely decency norms, religious norms and moral norms. Thus, narrowing the possibility of cancellation of the grant due to bad behavior of the grantee after getting the grant property. And the Land Title Registrar/Notary Officer also plays an important role in making the grant deed before the grant is ratified by the parties, because the Land Title Registrar /Notary Officer has the right to provide legal counseling related to the Grant.

\footnotetext{
${ }^{1}$ Daeng Naja, Deed Making Technique, Yustisia Library,Yogyakarta,2012, p. 1.

${ }^{2}$ Bahder Johan and Sri Warjiyati, Indonesian Law, Citra Aditya Bakti, 2001, p. 105

${ }^{3}$ I.G. Rai Widjaya, Drafting a Contract, Kesaint Blanc, Jakarta, 2007, p.13.
} 


\section{REFERENCE}

Abdul Manap. 2006. Various Problems of Islamic Civil Law in Indonesia, Kencana, Jakarta.

Adrian Sutedi. 2009. Transfer of Land Rights, Sinar Graphic, Jakarta.

Anke Dwi Saputro. 2008. Ed Identity Indonesian Notary, Past, Present, and Future, Gramedia Pustaka Utama, Jakarta.

Bahder Johan Nasution. 2008. Legal Research Methods, Mandar Maju, Bandung. . and Sri Warjiyati. 2001. Indonesian Law, Citra Aditya Bakti, Surabaya.

Boedi Harsono. 2005. Indonesian Agrarian Law-History of Formation of Basic Agrarian Laws, Content and Implementation, Djambatan, Jakarta.

G. H. S. Lumban Tobing. 1996. Regulation of Notary Position, Erlangga, Jakarta.

Habib Adjie. 2007. Civil and Administrative Sanctions Against Notaries as Public Officials, Refika Aditama, Bandung.

. (a) 2011. Knitting Thoughts in the World of Notaries \& PPAT. Citra Aditya Bakti, Bandung.

(b) 2011. Observing the Khazanah of Notaries and PPAT. Citra Aditya Bakti, Bandung.

R. Subekti. 1992. Various Agreements, Citra Aditia Bakti, Bandung.

Herlien Budiono. 2010. General Doctrine of Covenant Law and Its Application in Notary Sector. Citra Aditya Bakti, Bandung.

Zul Fadli. 2020. Notary Deed Law, Notary Circle, Jambi.

La Ode Angga. 2016. Legal Consequences of the Lack of Supervision and Evaluation of Spatial Planning in the Maluku Provincial RTRW Perda, Journal of Legal Studies, Vol.1, No. 2. 